\title{
Desain dan Simulasi Dual Input Single Output Buck Converter dengan Kontrol Fuzzy
}

\author{
(Design and Simulation of Dual Input Single Output Buck Converter \\ with Fuzzy Control)
}

\author{
Abdul Rahman Wachid ${ }^{1}$, Endro Wahjono ${ }^{2}$, Syechu Dwitya Nugraha ${ }^{3}$
}

\begin{abstract}
In this paper, a dual input single output buck converter with fuzzy control is designed and simulated for a DC load supply using the PSIM software. The dual input single output buck converter can work with two different sources. The use of the two power sources of photovoltaic and wind turbine is an alternative solution for obtaining a greater rated power to supply DC loads. The solar panel and the wind turbine will supply the power for the dual input buck converter circuit simultaneously. For the two power sources to work simultaneously, the duty cycle is set using fuzzy control, so that the output voltage can match the desired voltage. Simulation testing is carried out with photovoltaic conditions with varying irradiation and temperature values, as well as varying wind speeds in the wind turbine, i.e, between 4-8 $\mathrm{m} / \mathrm{s}$. The simulation results show that the dual-input single-output buck converter can work when powered by two different power sources with a stable output voltage of the converter at its set point, i.e., 14.4 volts.
\end{abstract}

Intisari-Dalam makalah ini didesain dan disimulasikan dual input single output buck converter dengan kontrol fuzzy untuk suplai beban DC dengan menggunakan software PSIM. Dual input single output converter dapat bekerja dengan dua sumber yang berbeda. Penggunaan dua sumber dari panel surya dan turbin angin adalah cara alternatif untuk mendapatkan nilai daya output yang lebih besar untuk suplai beban DC. Sumber dari panel surya dan turbin angin akan masuk ke dalam sistem rangkaian dual input buck converter secara bersamaan dengan kondisi sumber terpasang secara seri. Agar kedua sumber dapat bekerja secara bersamaan, duty cycle diatur menggunakan kontrol fuzzy sehingga tegangan output sesuai dengan yang diinginkan. Simulasi dilakukan dengan kondisi panel surya yang memiliki nilai iradiasi dan temperatur berubah-ubah serta turbin angin yang juga terkena angin dengan kecepatan tidak tetap, yaitu antara $4-8 \mathrm{~m} / \mathrm{s}$. Hasil simulasi menunjukkan bahwa dual input single output buck converter dapat bekerja dalam keadaan disuplai oleh dua sumber yang berbeda dengan tegangan output converter yang stabil di set point, yaitu 14,4 volt.

Kata Kunci-Dual Input Single Output Buck Converter, Fotovoltaik, Turbin Angin, Kontrol Fuzzy.

\section{Pendahuluan}

Sumber energi listrik adalah kebutuhan manusia yang sangat penting dan tidak dapat terlepaskan dari keperluan kehidupan

1,2,3 Departemen Teknik Elektro, Politeknik Elektronika Negeri Surabaya, Jl. Raya ITS, Sukolilo, Surabaya 6011 (tlp: 031-5947280; fax: 031-5946114; $\quad$ e-mail: ${ }^{1}$ wachid.its@gmail.com,
${ }^{2}$ endro@pens.ac.id, ${ }^{3}$ syechu@pens.ac.id) harian manusia. Konversi sumber energi hibrida seperti energi yang dihasilkan dari panel surya (fotovoltaik) dan energi turbin angin menjadi sumber listrik semakin berkembang. Penggunaan energi dari panel surya sebagai sumber listrik semakin digemari dan dijadikan sebuah riset karena sumber listrik yang dihasilkan oleh panel surya tidak menghasilkan polusi udara. Demikian juga dengan energi angin, sumber energi ini termasuk salah satu sumber energi yang dikategorikan sebagai energi yang sangat ramah lingkungan, sehingga sangat membantu mengurangi penggunaan energi bahan bakar fosil yang ketersediaannya semakin hari semakin berkurang. Penggunaan energi fotovoltaik dan turbin angin sebagai sumber energi terbarukan adalah cara mengatasi masalah atas terjadinya perubahan lingkungan dan alam. Misalnya, di Indonesia ketika musim kemarau matahari bersinar terang sehingga energi listrik yang dapat dihasilkan oleh panel surya cukup baik, sehingga saat musim kemarau energi listrik dari panel surya dapat dimanfaatkan secara maksimal. Kemudian, di musim penghujan, ketika kondisi mendung angin biasanya bertiup kencang, sehingga energi listrik dari turbin angin dapat dimanfaatkan secara maksimal [1].

Dewasa ini, pembangkitan energi listrik terbarukan semakin berkembang. Banyak perkembangan dan teknik yang dapat diterapkan dalam mendapatkan energi listrik tenaga hibrida. Dalam makalah ini diterapkan pembangkit listrik energi terbarukan dengan memadukan tenaga panel surya dan turbin angin sehingga lebih andal dalam menyuplai tenaga secara kontinu, daripada bekerja secara terpisah, dengan mengatur duty cycle dari masing-masing sumber [2]. Tujuan dari makalah ini adalah membuat sistem multi-input hibrida dengan sumber dari panel surya dan tenaga angin yang terhubung ke dalam satu converter dan memiliki keuntungan sebagai berikut: 1) daya dari array panel surya atau turbin angin dapat dikirim ke converter secara individual atau bersamaan; 2) berbagai variasi tegangan input yang disebabkan oleh perbedaan insolasi dan kecepatan angin dapat diterima [3].

Pada makalah ini dibuat sistem rangkaian multi-input hibrida dengan sumber daya dari panel surya dan sumber daya turbin angin. Agar daya yang dihasilkan untuk suplai beban DC tersebut lebih optimal, diterapkan teknologi elektronika daya yaitu dual input converter yang mengombinasikan dua sumber tersebut dengan mengatur nilai duty cycle pada masing-masing sumber. Diagram blok sistem ditampilkan pada Gbr. 1 dan diimplementasikan dalam software PSIM. 


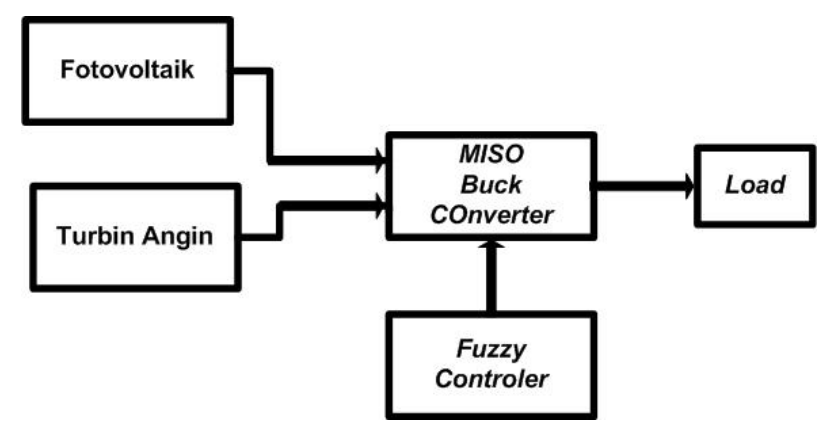

Gbr. 1 Diagram blok sistem.

\section{KONFIGURASI SISTEM}

Untuk merancang sebuah sistem dual input single output buck converter dengan sumber tenaga panel surya dan turbin angin diperlukan beberapa komponen yang akan dijelaskan sebagai berikut.

\section{A. Fotovoltaik}

Sel surya atau solar cell merupakan komponen yang dapat mengubah energi cahaya matahari menjadi energi listrik dengan menggunakan prinsip efek fotovoltaik. Daya yang dihasilkan dari sel surya bernilai kecil. Oleh karena itu, sel-sel surya dihubungkan secara seri atau paralel atau seri-paralel menjadi panel surya. Rangkaian ekivalen panel surya ditunjukkan pada Gbr. 2 [4]. Parameter panel surya yang digunakan pada sistem ini disajikan pada Tabel I.

Karakteristik perbandingan arus-tegangan (I-V) dari panel surya dapat dinyatakan sebagai (1) [5].

$$
I_{P V}=I_{P V n}-\left(I_{O}\left(\frac{V_{D}}{e^{a V_{T}}}-1\right)-\frac{V_{P V}+I_{P V} R_{S}}{R_{P}}\right.
$$

dengan Ipv merupakan arus output (A), $V_{p v}$ adalah tegangan output $(\mathrm{V}), I_{p v}$ adalah arus nominal (A), $I_{o}$ adalah current reverse diode (A), $R_{s}$ merupakan hambatan seri panel surya (ohm), $R p$ merupakan hambatan paralel panel surya (ohm), dan $a$ adalah diode ideality factor.

\section{B. Turbin Angin}

Angin adalah udara yang bergerak dari daerah dengan tekanan udara tinggi ke daerah dengan tekanan udara yang lebih rendah. Perbedaan tekanan udara disebabkan oleh adanya pancaran sinar matahari yang tidak merata. Karena bergerak, angin akan memiliki energi kinetik. Energi angin dapat dikonversi atau ditransfer ke dalam bentuk energi listrik atau mekanik dengan menggunakan turbin angin. Jumlah energi angin yang ditangkap kincir turbin tergantung pada ukuran baling-baling dan kecepatan turbin angin, yang dapat dinyatakan dengan (2) [6].

$$
P w t=\frac{1}{2} \pi R^{2} \rho v^{3}
$$

dengan $R$ merupakan nilai jari-jari turbin angin, $\rho$ merupakan densitas angin yang didapatkan turbin angin, dan $v$ merupakan kecepatan angin yang ditangkap oleh turbin angin. Daya mekanik yang mampu didapatkan oleh turbin angin ditentukan oleh efisiensi yang dinyatakan dengan (3) [7]. Parameter panel surya yang digunakan pada sistem ini disajikan pada Tabel II.

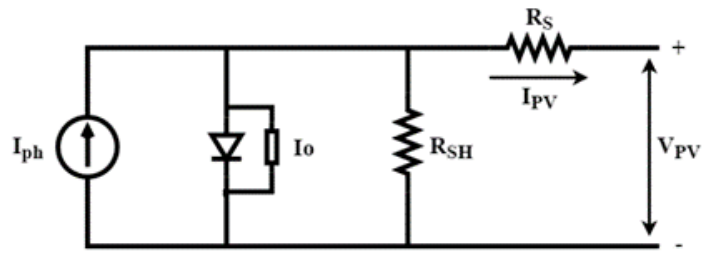

Gbr. 2 Rangkaian dual input single output buck converter.

TABEL I

PARAMETER PANEL SURYA

\begin{tabular}{|l|l|}
\hline \multicolumn{1}{|c|}{ Parameter } & Nilai \\
\hline Daya maksimum $\left(P_{\max }\right)$ & 100 watt \\
\hline Arus maksimum $\left(I_{m p}\right)$ & 5,81 ampere \\
\hline Arus short circuit $\left(I_{s c}\right)$ & 6,46 ampere \\
\hline Tegangan maksimum $\left(V_{m p}\right)$ & 17,2 volt \\
\hline Tegangan open circuit $\left(V_{o c}\right)$ & 21,6 volt \\
\hline Koefisien temperatur $V_{o c}$ & $-0,38 \% /{ }^{\circ} \mathrm{C}$ \\
\hline Koefisien temperatur $I_{s c}$ & $0,065 \% /{ }^{\circ} \mathrm{C}$ \\
\hline
\end{tabular}

TABEL II

PARAMETER TURBIN ANGIN

\begin{tabular}{|l|l|}
\hline \multicolumn{1}{|c|}{ Parameter } & Nilai \\
\hline Daya maksimum $\left(P_{\max }\right)$ & 1.000 watt \\
\hline Tegangan fase & $380 \mathrm{volt}$ \\
\hline Frekuensi & $50 \mathrm{~Hz}$ \\
\hline Base speed & $2 \mathrm{~m} / \mathrm{s}$ \\
\hline Momen of inertia & 1 \\
\hline
\end{tabular}

$$
P m=\frac{1}{2} \eta \pi \rho R^{2} v^{3}
$$

\section{Dual Input Single Output Buck Converter}

Multi-input converter merupakan terobosan riset teknologi elektronika daya dengan sebuah konverter yang dapat bekerja dengan dua sumber yang memiliki karakteristik berbeda dan digabungkan secara paralel maupun seri agar dapat menyuplai beban DC secara lebih optimal [8]. Dalam makalah ini digunakan converter berjenis buck converter dengan dua sumber untuk meregulasi tegangan input dari panel surya dan turbin angin.

\section{Mode Operasi Dual Input Single Output Buck Converter}

Dual input single output buck converter memiliki empat mode operasi dalam satu periode switching. Untuk dapat menganalisis kinerja mode operasi converter, diasumsikan semua komponen dalam converter dianggap ideal dan tidak memiliki rugi-rugi tahanan dalam dan kondisi converter beroperasi secara Continuous-Continuous Conduction Mode (CCCM) atau arus induktor $i_{L}$ selalu kontinu [9].

1) Mode 1: Pada mode pertama, seperti terlihat pada Gbr. 3, saat kondisi MOSFET1 (S1) on dan MOSFET2 (S2)off, maka diode (D1) akan bekerja secara reverse, kemudian tegangan DC2 diblok oleh MOSFET2 (S2) sehingga diode (D2) akan aktif dan bekerja secara forward. Akibatnya, arus dari sumber DC1 akan bekerja menyuplai induktor, kapasitor, dan resistor beban [10].

2) Mode 2: Pada mode kedua, seperti terlihat pada Gbr. 4, saat kondisi MOSFET1 (S1) off dan MOSFET2 (S2) on, maka 


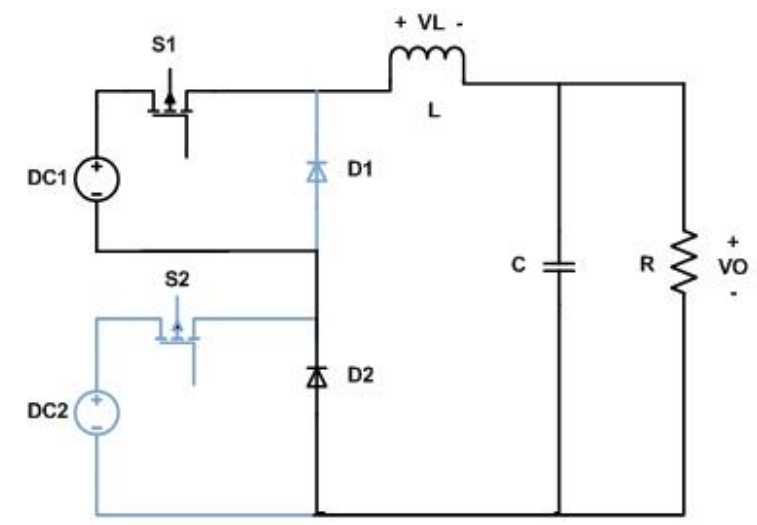

Gbr. 3 Operasi dual input single output buck converter mode 1.

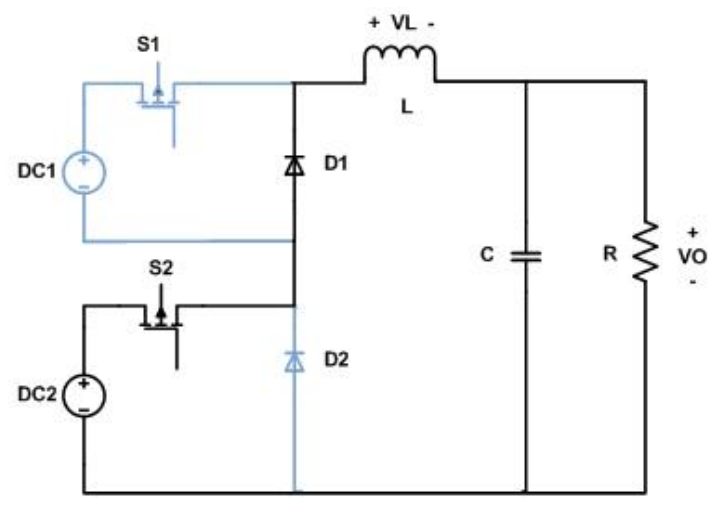

Gbr. 4 Operasi dual input single output buck converter mode 2.

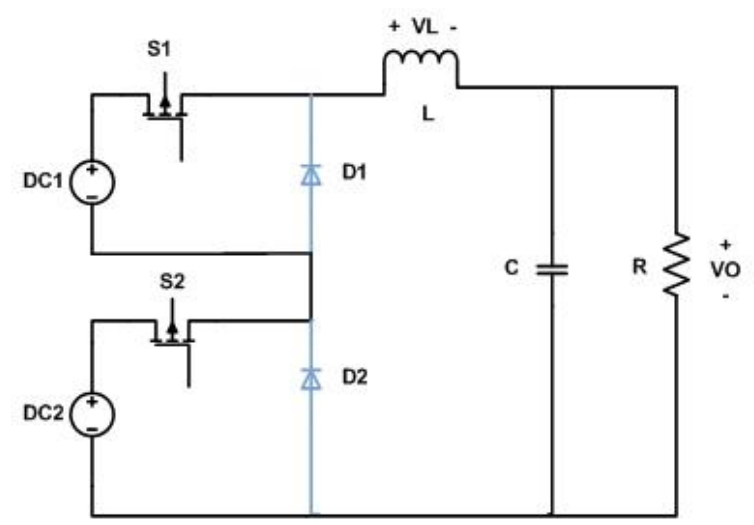

Gbr. 5 Operasi dual input single output buck converter mode 3.

diode (D2) akan bekerja secara reverse, kemudian sumber tegangan DC1 diblok oleh MOSFET1 (S1), sehingga diode (D1) bekerja secara forward dan arus dari sumber DC2 akan bekerja menyuplai induktor, kapasitor, dan resistor beban.

3) Mode 3: Pada mode ketiga, seperti pada Gbr. 5, saat kondisi MOSFET1 (S1) on dan MOSFET2 (S2) on, diode (D1) dan (D2) akan bekerja secara reverse. Sumber DC1 dan sumber DC2 akan bekerja menyuplai induktor, kapasitor, dan resistor beban secara seri.

4) Mode 4: Pada mode keempat, seperti ditunjukkan pada Gbr. 6, saat kondisi MOSFET1 (S1) off dan MOSFET2 (S2) off, diode (D1) dan (D2) akan bekerja secara forward. Sumber DC1 dan sumber DC2 tidak dapat menyuplai beban karena

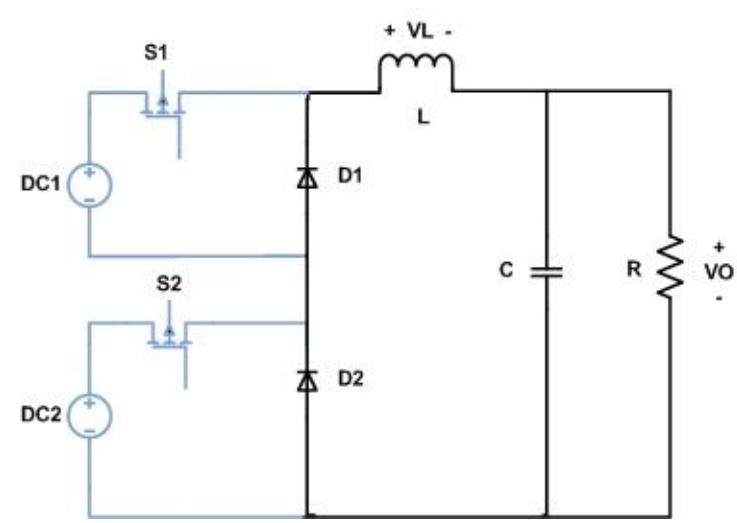

Gbr. 6 Operasi dual input single output buck converter mode 4.

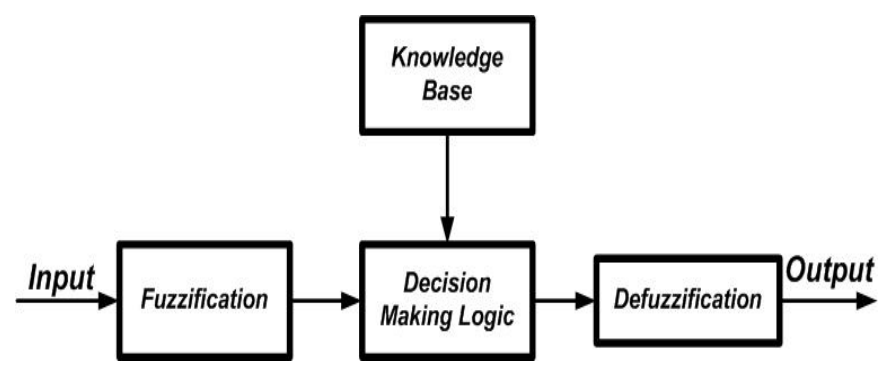

Gbr. 7 Struktur dasar sistem fuzzy.

TABEL III

PARAMETER DUAL INPUT SINGLE OUTPUT BUCK CONVERTER

\begin{tabular}{|l|l|}
\hline \multicolumn{1}{|c|}{ Parameter } & Nilai \\
\hline Tegangan input 1 & $17,5 \mathrm{~V}$ \\
\hline Tegangan input 2 & $40 \mathrm{~V}$ \\
\hline Tegangan output & $14,4 \mathrm{~V}$ \\
\hline Switching frequency & $40 \mathrm{kHz}$ \\
\hline Efisiensi & $80 \%$ \\
\hline Ripple $V_{O}$ & $1 \%$ \\
\hline Ripple $I_{L}$ & $5 \%$ \\
\hline
\end{tabular}

MOSFET1 dan MOSFET2 dalam kondisi off, sehingga arus yang akan mengalir menuju kapasitor dan resistor berasal dari induktor yang mengalami discharge.

Penentuan nilai tegangan output $\left(V_{o}\right)$ dari keempat mode operasi converter adalah sebagai berikut [11].

Kondisi switch menutup (close) dinyatakan dengan (4).

$$
V_{L}=V_{1}+V_{2}-V_{0}=L \frac{d i l}{d t}
$$

maka,

$$
\begin{gathered}
\frac{V_{1}+V_{2}-V_{0}}{L}=\frac{d i l}{d t} \\
\frac{d i l}{d t}=\frac{\Delta i l}{\Delta t}=\frac{\Delta i l}{\Delta D T} \\
\Delta i l(\text { close })=\frac{V_{1}+V_{2}-V_{0}}{L} \times D T .
\end{gathered}
$$

Kondisi switch terbuka (open) dinyatakan sebagai berikut.

$$
\begin{gathered}
V_{L}=-V_{0}=L \frac{d i l}{d t} \\
V_{L}=-\frac{V_{0}}{L}
\end{gathered}
$$




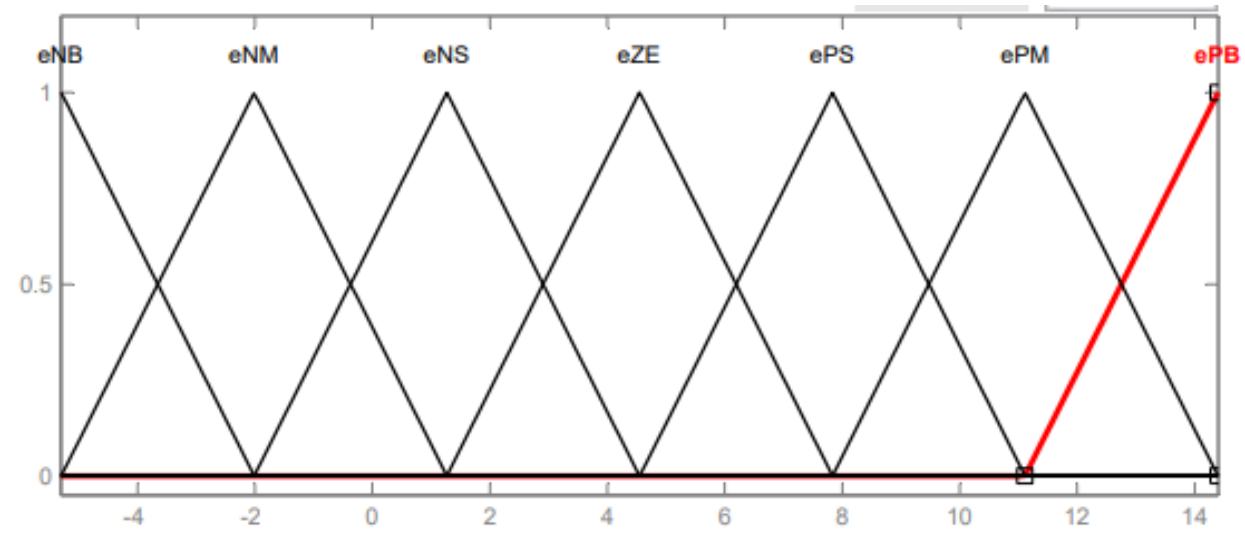

Gbr. 8 Input variabel error.

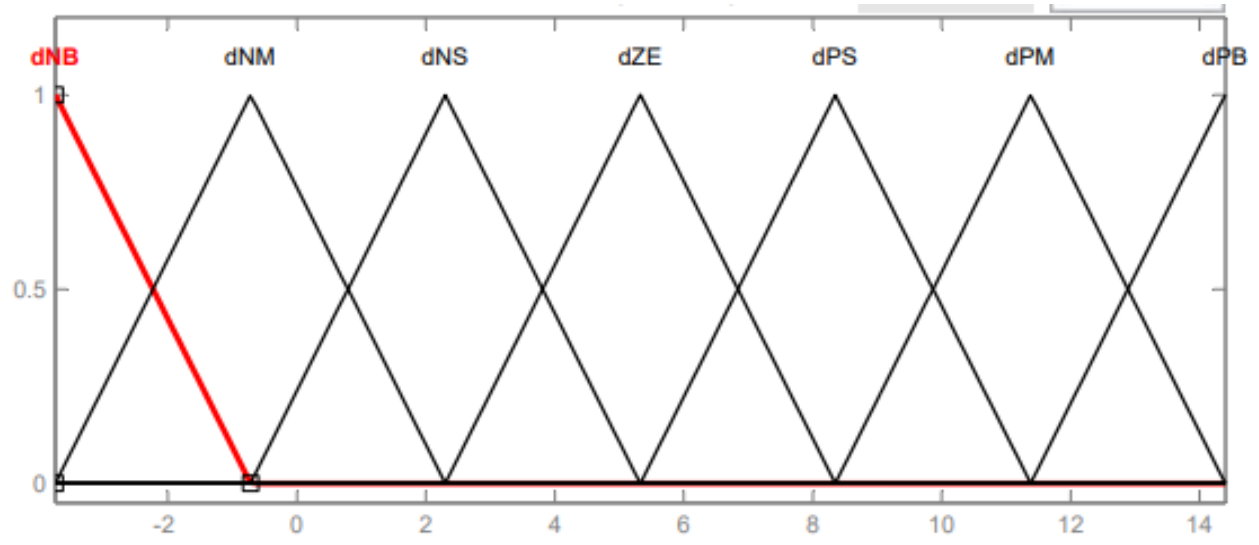

Gbr. 9 Input variabel delta error.

$$
\begin{gathered}
\frac{\Delta i l}{\Delta t}=\frac{\Delta i l}{(1-D) T}=-\frac{V_{0}}{L} \\
\Delta i l(\text { open })=-\frac{V_{0}}{L} \times(1-D) T .
\end{gathered}
$$

Persamaan dasar tegangan output multi-input buck converter sama dengan diperoleh sebagai berikut.

$$
\begin{gathered}
\Delta i l(\text { open })+\Delta i l(\text { close })=0 \\
\left(\frac{V_{1}+V_{2}-V_{0}}{L} \times D T\right)+\left(-\frac{V_{0}}{L} \times(1-D) T\right)=0 \\
\left(\frac{V_{1} D T+V_{2} D T-V_{0} D T}{L}\right)-\left(\frac{V_{O} T+V_{O} D T}{L}\right)=0 \\
V_{1} D+V_{2} D-V_{0} D-V_{0}+V_{0} D=0 \\
V_{0}=V_{1} D+V_{2} D .
\end{gathered}
$$

Dalam mendesain sebuah converter, harus ditentukan nilai parameter yang digunakan sesuai dengan sistem, agar hasil yang diharapkan dapat tercapai. Parameter hasil perencanaan dual input single output buck converter ini ditunjukkan pada Tabel III [12], yang merupakan desain yang dinginkan dalam makalah ini.

\section{E. Kontrol Fuzzy}

Pada makalah ini kontrol yang digunakan untuk mengatur tegangan keluaran converter agar sesuai dengan set point adalah kontrol logika fuzzy. Kontrol logika fuzzy akan mengatur keluaran duty cycle dari dual input single output buck converter agar mengeluarkan tegangan output yang sesuai dengan set point, yaitu 14,4 volt. Kontrol logika fuzzy akan membandingkan nilai tegangan output yang terdeteksi dengan set point yang ditentukan, sehingga didapatkan nilai "error" dan "delta error". Nilai output fuzzy dinamakan duty cycle. Nilai tersebut akan digunakan untuk mengatur duty cycle converter. Kontrol fuzzy ini mempunyai beberapa tahap sebelum menuju plant. Tahapan-tahapan tersebut adalah fuzzification, rule base beserta database, kemudian defuzzification. Proses logika fuzzy ditunjukkan seperti pada Gbr. 7 [13], [14].

1) Fuzzification: Fuzzification adalah proses transformasi nilai crisp input menjadi nilai fuzzy (varaibel linguistik) yang tersaji dalam bentuk sebuah himpunan fuzzy dengan masingmasing membership function. Gbr. 8. dan Gbr. 9 menunjukkan proses Fuzzification.

2) Rule Base: Aturan-aturan fuzzy (rule base) biasanya menggunakan pernyataan "jika-maka" yang menggambarkan aksi yang diambil dalam merespons bermacam-macam masukan fuzzy. Aturan-aturan mengikuti perilaku umum sistem dan ditulis dalam pola tabel linguistik fungsi keanggotaan. Tabel IV merupakan rule base yang digunakan dalam makalah ini, dengan $\mathrm{E}=$ error, $\Delta \mathrm{E}=$ delta error, $\mathrm{PB}=$ positive big, $\mathrm{PM}$ = positive middle, $\mathrm{PS}=$ positive small, $\mathrm{ZE}=$ zero, $\mathrm{NS}=$ negative small, $\mathrm{NM}=$ negative middle, $\mathrm{NB}=$ negative big . 
TABEL IV

RULE BASE PADA KONTROL FUZZY

\begin{tabular}{|c|c|c|c|c|c|c|c|}
\hline $\mathbf{E} / \Delta \mathbf{E}$ & NB & NM & NS & ZE & PS & PM & PB \\
\hline PB & PS & PS & NS & NS & ZE & PM & PM \\
\hline PM & PM & PS & PB & PS & ZE & PM & PM \\
\hline PS & PB & PM & PB & PB & PS & PM & PS \\
\hline ZE & PM & PB & PM & PS & PS & PM & PS \\
\hline NS & PM & PM & PS & PS & PS & PM & ZE \\
\hline NM & PS & PS & PS & PS & PS & PS & PS \\
\hline NB & PS & PS & PS & PS & PS & PS & PS \\
\hline
\end{tabular}

Tegangan PV Tegangan Turbin Angin Tegangan Output Converter

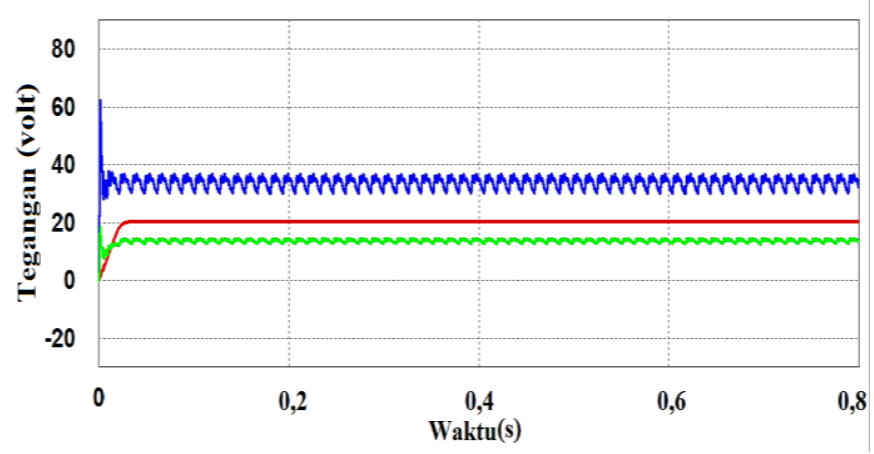

Gbr. 10 Respons tegangan ouput converter tanpa kontrol.

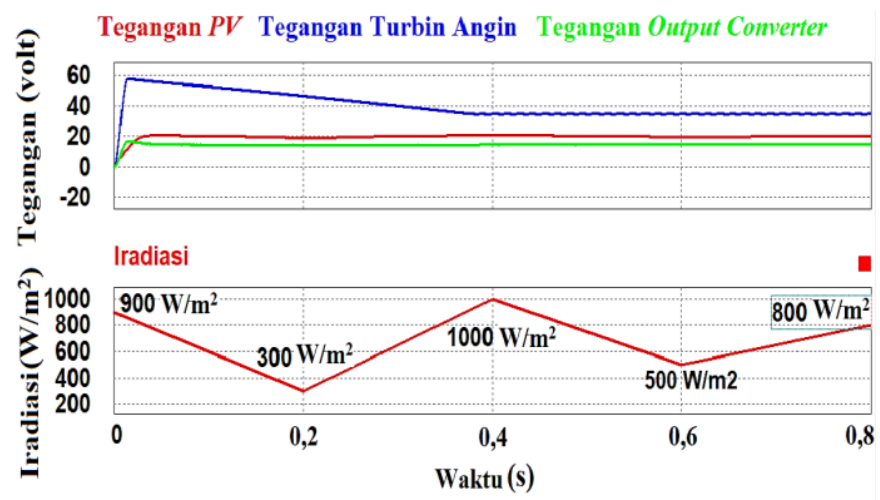

Gbr. 11 Respons tegangan output saat diberi gangguan pada sisi iradiasi dengan nilai $300-1.000 \mathrm{~W} / \mathrm{m} 2$.

3) Defuzzification: Output dari rule base berbentuk nilai fuzzy. Maka, proses defuzzification diperlukan untuk mentransformasikan sebuah nilai fuzzy (variabel linguistik) menjadi nilai dalam bentuk duty cycle yang digunakan untuk mengatur switching dari MOSFET converter [15].

\section{HASIL SIMULASI DAN ANALISIS}

Pengujian dual input single output buck konverter dengan kontrol fuzzy dilakukan menggunakan simulasi pada software PSIM (aplikasi simulasi di bidang elektronika daya). Pada simulasi ini digunakan dua sumber input berupa panel surya dan turbin angin, Beban yang digunakan adalah resistor dengan nilai sesuai perhitungan converter. Pada simulasi ini digunakan sumber panel surya dengan daya $100 \mathrm{WP}$ dan daya sumber turbin angin $1.000 \mathrm{~W}$. Panel surya dipasang sebagai sumber pertama (DC1), sedangkan turbin angin dipasang pada sumber kedua (DC2). Penelitian ini juga sedang dikembangkan secara real menggunakan hardware, sehingga penggunaan besar daya

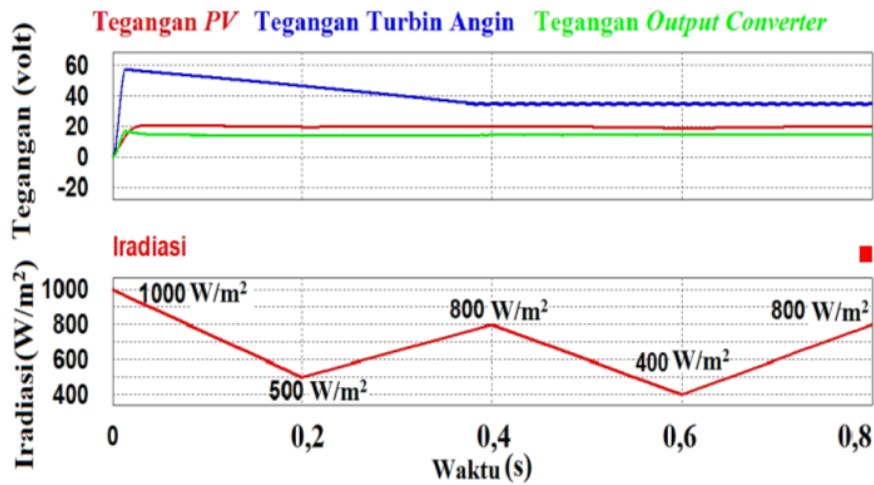

Gbr. 12 Respons tegangan output saat diberi gangguan pada sisi iradiasi dengan nilai $400-1.000 \mathrm{~W} / \mathrm{m}^{2}$.

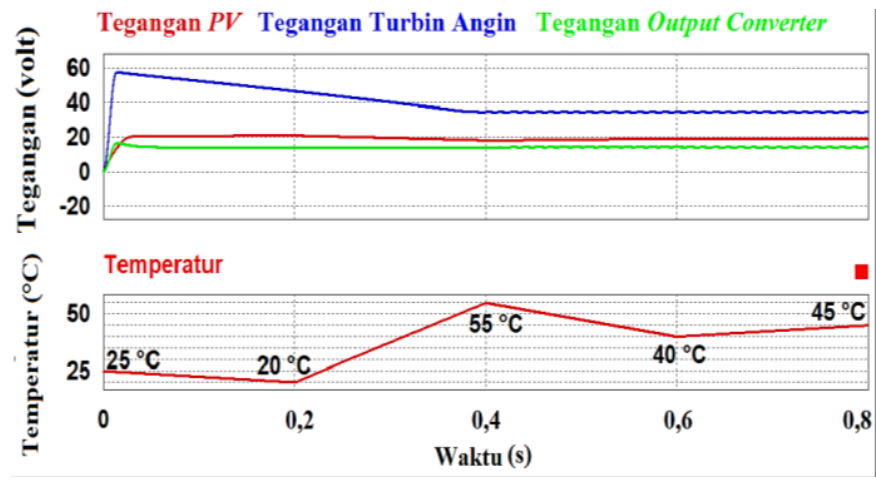

Gbr. 13 Respons tegangan output saat diberi gangguan pada sisi temperatur dengan nilai $20-55^{\circ} \mathrm{C}$.

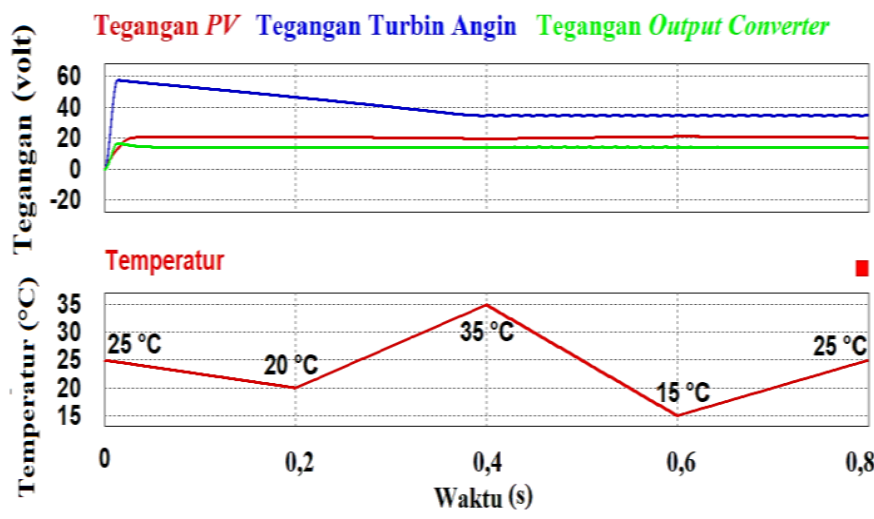

Gbr. 14 Respons tegangan output saat diberi gangguan pada sisi temperatur dengan nilai $15-35^{\circ} \mathrm{C}$.

masing-masing sumber pada simulasi ini disesuaikan dengan riset pada hardware.

Simulasi yang pertama dilakukan dengan mecoba rangkaian dual input single output buck converter tanpa kontrol dengan sumber daya dari panel surya dan turbin angin, dengan nilai duty cycle sebesar $25,05 \%$. Respons output tegangan saat tidak menggunakan kontrol ditunjukkan pada Gbr. 10. Sumbu y mewakili tegangan dengan satuan volt. Terlihat bahwa tegangan output converter tidak bernilai sesuai set point 14,4 volt.

Rangkaian dual input single output buck converter dengan kontrol fuzzy ditunjukkan pada Gbr L1 pada lampiran. Hasil 


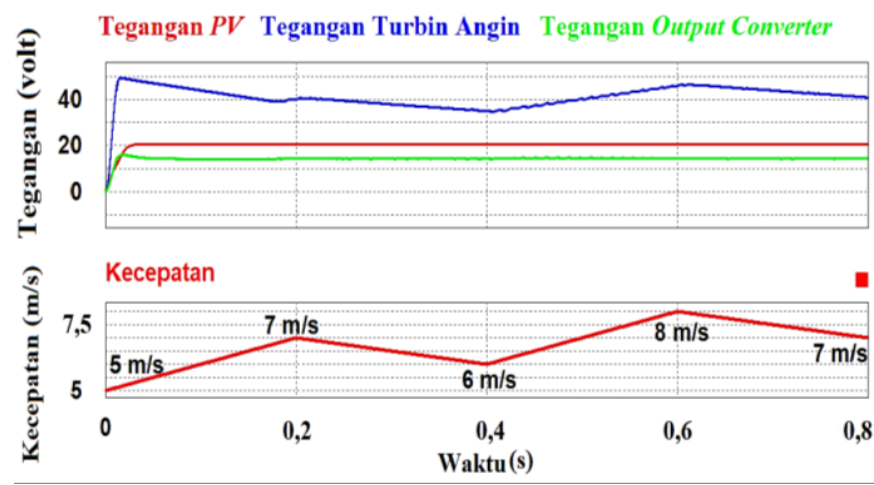

Gbr. 15 Respons tegangan output saat diberi gangguan pada sisi wind speed dengan nilai $5-8 \mathrm{~m} / \mathrm{s}$.

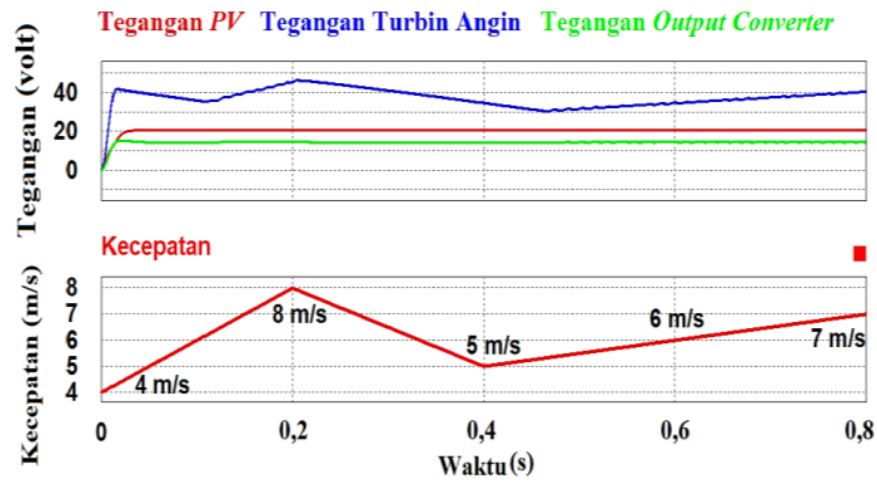

Gbr. 16 Respons tegangan output saat diberi gangguan pada sisi wind speed dengan nilai $4-8 \mathrm{~m} / \mathrm{s}$.
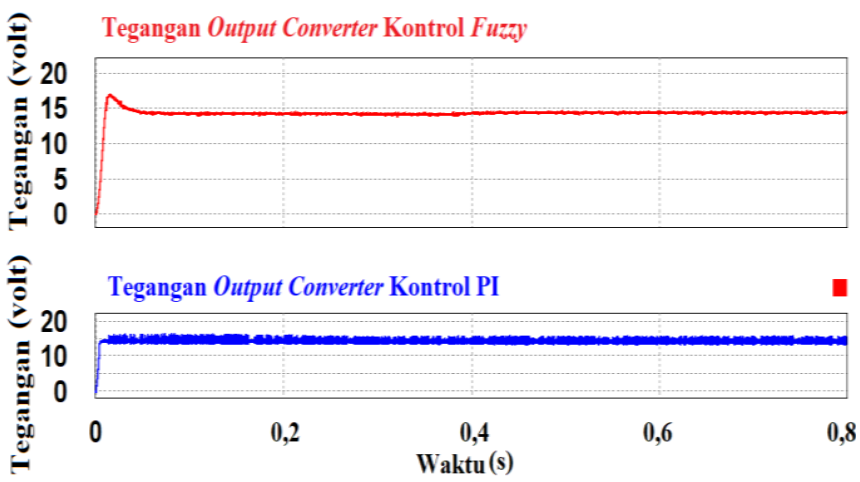

Gbr. 17 Perbandingan respons output converter dengan kontrol fuzzy dan dengan kontrol PI.

respons tegangan output kondisi 1 ditunjukkan pada Gbr. 11, dengan sisi input panel surya diberi gangguan pada detik $0 \mathrm{~s}$, $0,2 \mathrm{~s}, 0,4 \mathrm{~s}, 0,6 \mathrm{~s}$, dan $0,8 \mathrm{~s}$. Saat menggunakan kontrol fuzzy, rangkaian menghasilkan tegangan output yang stabil di 14,4 volt, walaupun nilai iradiasi berubah-ubah, yaitu pada saat $0 \mathrm{~s}$, iradiasinya $900 \mathrm{~W} / \mathrm{m}^{2}$; pada saat $0,2 \mathrm{~s}$, iradiasinya $300 \mathrm{~W} / \mathrm{m}^{2}$; pada saat $0,4 \mathrm{~s}$, iradiasinya $1.000 \mathrm{~W} / \mathrm{m}^{2}$; pada saat $0,6 \mathrm{~s}$, iradiasinya $500 \mathrm{~W} / \mathrm{m}^{2}$, dan pada saat $0,8 \mathrm{~s}$, iradiasinya 800 $\mathrm{W} / \mathrm{m}^{2}$.

Grafik pada Gbr. 12 menunjukkan respons ketika rangkaian dual input single output buck converter dengan kontrol fuzzy diberi gangguan pada sisi iradiasi. Pada kondisi 2 ini, gangguan diberikan pada detik $0 \mathrm{~s}, 0,2 \mathrm{~s}, 0,4 \mathrm{~s}, 0,6 \mathrm{~s}$, dan 0,8 s. Respons output tegangan saat menggunakan kontrol fuzzy menghasilkan
Daya PV Daya Turbin Angin Daya Output Converter

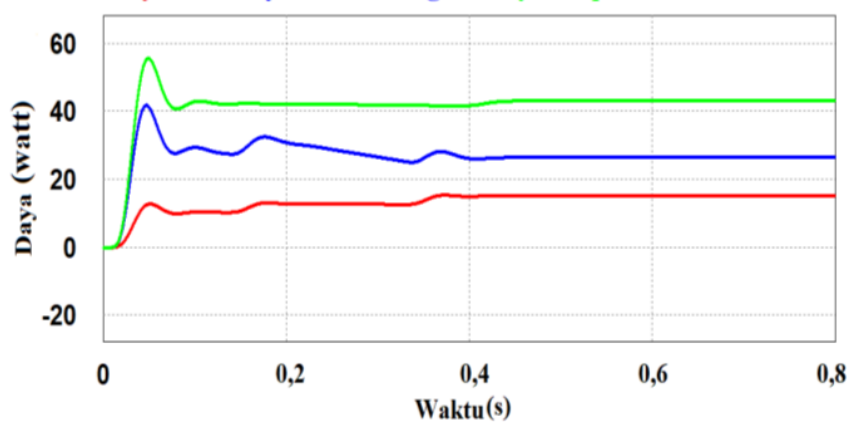

Gbr. 18 Perbandingan daya panel surya, turbin angin, dan output converter. TABEL V

HASIL Simulasi DUAL INPUT SINGLE OUTPUT BUCK CONVERTER DENGAN KONTROL FUZZY

\begin{tabular}{|c|c|c|c|c|}
\hline No. & $\begin{array}{c}\text { Letak } \\
\text { Gangguan }\end{array}$ & $\begin{array}{c}\text { Vout Simulasi } \\
(\mathbf{v o l t})\end{array}$ & $\begin{array}{c}\text { Set Point } \\
(\mathbf{v o l t})\end{array}$ & $\begin{array}{c}\text { Error } \\
(\boldsymbol{\%})\end{array}$ \\
\hline $\mathbf{1 .}$ & Iradiasi & 14,4 & 14,4 & 0 \\
\hline $\mathbf{2 .}$ & Iradiasi & 14,4 & 14,4 & 0 \\
\hline $\mathbf{3 .}$ & Temperatur & 14,4 & 14,4 & 0 \\
\hline $\mathbf{4 .}$ & Temperatur & 14,4 & 14,4 & 0 \\
\hline $\mathbf{5 .}$ & Speed & 14,42 & 14,4 & 0,138 \\
\hline $\mathbf{6 .}$ & Speed & 14,41 & 14,4 & 0,073 \\
\hline
\end{tabular}

tegangan output stabil di 14,4 volt walapun nilai iradiasi berubah-ubah.

Grafik pada Gbr. 13 menunjukkan hasil simulasi dengan kondisi 3. Respons output tegangan saat menggunakan kontrol fuzzy menghasilkan tegangan output stabil di 14,4 volt walaupun nilai temperaturnya berubah-ubah, yaitu pada waktu $0 \mathrm{~s}$, temperaturnya $25^{\circ} \mathrm{C}$; pada saat $0,2 \mathrm{~s}$, temperaturnya $20^{\circ} \mathrm{C}$, pada saat $0,4 \mathrm{~s}$, temperaturnya $55{ }^{\circ} \mathrm{C}$, pada saat $0,6 \mathrm{~s}$, temperaturnya $35^{\circ} \mathrm{C}$, dan pada saat $0,8 \mathrm{~s}$, temperaturnya $45^{\circ} \mathrm{C}$. Pada nilai-nilai temperatur tersebut, tegangan output converter stabil di 14,4 volt. Sementara itu, grafik pada Gbr. 14 adalah hasil simulasi dengan kondisi 4, yaitu respons output tegangan saat menggunakan kontrol fuzzy, yang menghasilkan tegangan output stabil di 14,4 volt walaupun nilai temperatur berubahubah.

Grafik pada Gbr. 15 dan Gbr. 16 menunjukkan hasil simulasi closed loop pada kondisi 5 dan kondisi 6, dengan gangguan diberikan pada waktu 0 s, 0.2 s, 0,4 s, 0,6 s, dan 0,8 s. Respons output tegangan saat menggunakan kontrol fuzzy menghasilkan tegangan tetap stabil di 14,4 volt walaupun masih ada ripple tegangan.

Grafik pada Gbr. 17 merupakan perbandingan respons tegangan output rangkaian dual input single output buck converter dengan sumber dari panel surya dan turbin angin. Dengan kontrol fuzzy, tegangan output converter dapat lebih stabil dan memiliki ripple tegangan output yang lebih kecil daripada tegangan output converter ketika digunakan kontrol PI. Terakhir, grafik pada Gbr. 18 merupakan perbandingan kontribusi daya yang dihasilkan masing-masing sumber dalam memenuhi daya beban converter. Panel surya menyuplai daya sebesar 13,73 W atau 33\% dari kebutuhan daya converter, sedangkan turbin angin menyuplai daya sebesar $27,4 \mathrm{~W}$ atau sekitar $67 \%$ kebutuhan daya converter. 


\section{KESIMPULAN}

Setelah dilakukan simulasi secara closed loop dengan sumber dari panel surya dan turbin angin, diperoleh data hasil simulasi seperti pada Tabel V. Data yang didapatkan menunjukkan tegangan output dual input single output buck converter rata-rata sebesar 14,4 volt, walaupun masih memiliki ripple sebesar 0,2 volt. Nilai rata rata error dari hasil simulasi closed loop ini sebesar 0,035\%. Dari hasil pengujian secara keseluruhan pada rangkaian dual input single output buck converter, dapat dilihat bahwa converter mampu meregulasi tegangan sesuai dengan tegangan yang diinginkan, yaitu sebesar 14,4 volt, yang disuplai oleh dua sumber, yaitu panel surya dan turbin angin. Meskipun masing-masing sumber tersebut memiliki karakteristik yang berbeda, converter ini mampu menstabilkan dan meregulasi tegangan output yang sesuai dengan set point yang diinginkan.

\section{REFERENSI}

[1] M.N.L. Adiyatma "Rancang Bangun Pembangkit Listrik Hibrida Pane Surya dan Turbin Angin sebagai Pengisian Energi pada Baterai," Tugas akhir, Institut Teknologi Sepuluh Nopember, Surabaya, Indonesia, 2018.

[2] L. Kumar dan S. Jain, "A Multiple Source DC/DC Converter Topology," Int. Journal of Electrical Power and Energy Systems, Vol. 51, hal. 278291, 2013.

[3] Y.M. Chen, S.C. Hung, C.S. Cheng, dan Y.C. Liu, "Multi-input Inverter for Grid-Connected Hybrid PV/Wind Power Sistem," IEEE Transactions on Power Electronics, Vol.22, No.3, hal. 1070-1077, 2005.

[4] N.A. Ahmed, M. Miyatake, dan A.K. Al-Othman, "Power Fluctutions Suppression of Stand-Alone Hybrid Generation Combining Solar Photovoltaic/Wind Turbine and Fuel Cell," Energy Conversion and Management, Vol. 49, No. 10, hal. 2711-2719.

[5] I. Sudiharto, F.D. Murdianto, Irianto, E. Sunarno, dan E. Wulandari, "Robustness Analysis of PI controller to Optimizing the Output Power for Energy Management in DC Microgrid System," 2019 2nd Int. Conf. on Applied Information Technology and Innovation (ICAITI), 2019, hal. 105-110.
[6] M.A. Akbar, "Rancang Bangun dc-dc Converter pada Pembangkit Listrik Tenaga Bayu (Wind Turbine) untuk Pengisian Baterai," Tugas akhir, Politeknik Elektronika Negeri Surabaya, Surabaya, Indonesia, 2018.

[7] F.A. Pamuji dan Soedibyo, "Desain Kontrol Multi-Input DC-DC Converter Sistem Hibrid Turbin Angin dan Sel Surya Menggunakan Kontrol Fuzzy Logic untuk Tegangan Rendah," Jurnal Nasional Teknik Elektro, Vol.4, No.2, hal. 220-226, 2019.

[8] S.D. Vidhya dan M. Balaji, "Hybrid Fuzzy PI Controlled Multi-Input DC/DC Converter for Electric Vehicle Application," Automatika, Vol. 61, No. 1, hal. 79-91, 2020.

[9] C.L. Shen, C.T. Tsai, Y.E. Wu, dan C.C. Chen "A Modified-Forward Multi-input Power Converter for Solar Energy and Wind Power Generator," 2009 Int. Conf. on Power Electronics and Drive Systems (PEDS), 2009, hal. 631-636.

[10] Z. Arifin, D.C. Riawan, dan H. Suryoatmojo, "Perancangan dan Implementasi Multi-Input Single-Output Konverter Buck untuk pengisian Baterai menggunakan Panel Surya dan Turbin Angin" Jurnal Teknik ITS, Vol. 5, No.2, hal. B83-B88, 2016.

[11] B.L.H. Nguyen, H. Cha, T.T. Nguyen, dan H.G. Kim "Family of Integrated Multi-Input Multi-Output DC-DC Power Converters," Int. Power Electroniscs Conference, 2018, hal. 3134-3139.

[12] M. Syahid "Rancang Bangun Dual Input Single Output Buck Converter dengan Sumber Daya dari Panel Surya dan PLN untuk Aplikasi Charger Baterai pada Penerangan Rumah DC," Tugas akhir, Politeknik Elektronika Negeri Surabaya, Surabaya, Indonesia, 2016.

[13] A.R. Nansur, A.S.L. Hermawan, F.D. Murdianto, "Constant Voltage Using Fuzzy Logic Controller (FLC) to Overcome the Unstable Output Voltage of MPPT in DC Microgrid System," 2018 Int. Electronics Symposium on Engineering Technology and Applications (IES-ETA), 2018, hal. 19-24.

[14] M.W. Alim, N.A. Windarko, R. Rakhmawati, "Fuzzy Logic Contro Design on Buck Converter for Thermo Electric Air Cooler Power Supply," Journal on Advanced Research in Electrical Engineering (JAREE), Vol. 4, No. 2, hal. 111-116, 2020.

[15] Sutedjo, O.A. Qudsi, A. Ardianto, D.S. Yanaratri, Suhariningsih, dan M Darwis "Design and Implementation Buck Converter for 540WP Solar Charger Using Fuzzy Logic Control,” ASTECHNOVA 2017 International Energy Conference, 2017, hal. 1-7. 


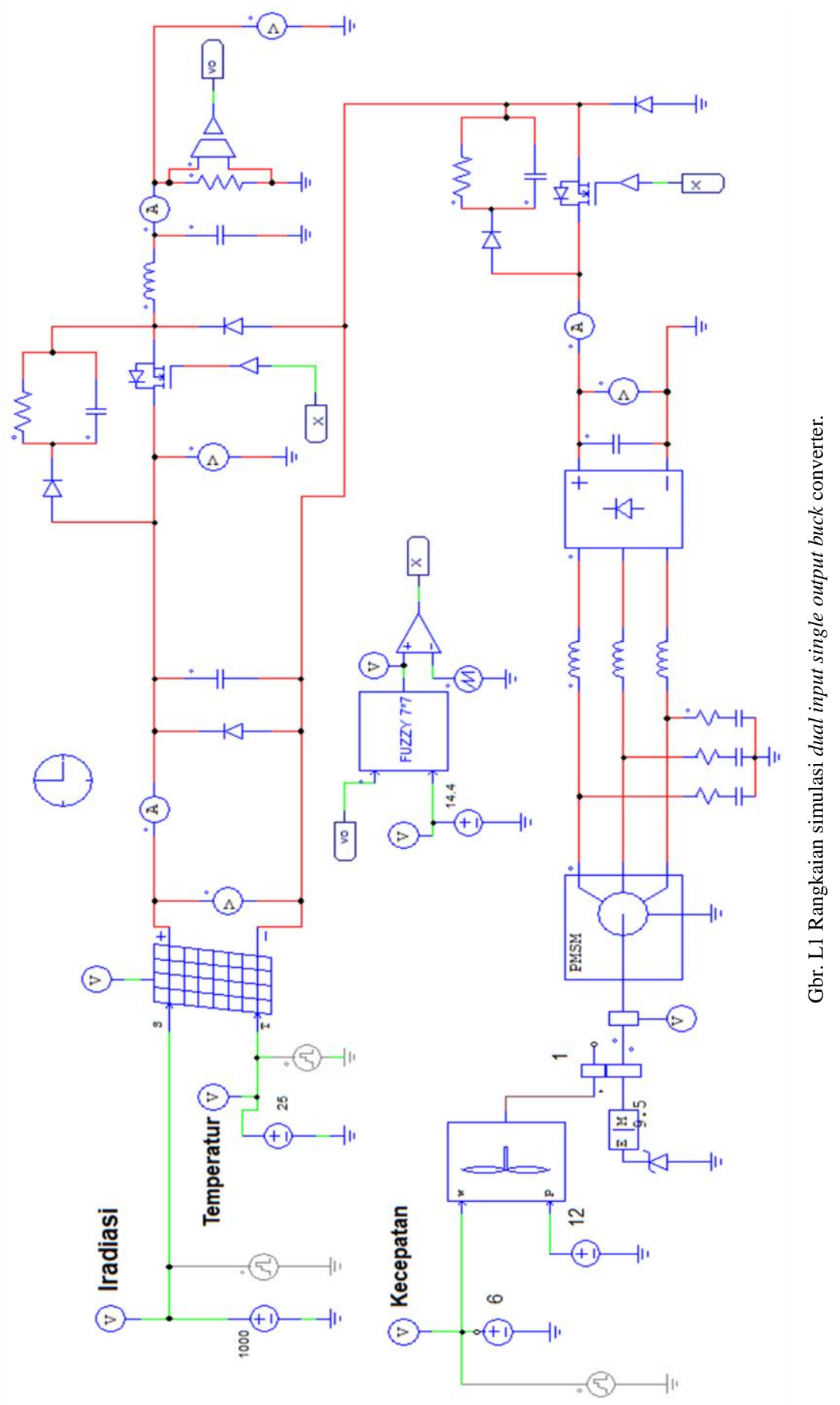

